\title{
African Languages
}

\section{Author(s): A. C. Madan}

Source: The Geographical Journal, Vol. 28, No. 5 (Nov., 1906), p. 516

Published by: geographicalj

Stable URL: http://www.jstor.org/stable/1776042

Accessed: 27-06-2016 10:38 UTC

\section{Your use of the JSTOR archive indicates your acceptance of the Terms \& Conditions of Use, available at}

http://about.jstor.org/terms

JSTOR is a not-for-profit service that helps scholars, researchers, and students discover, use, and build upon a wide range of content in a trusted digital archive. We use information technology and tools to increase productivity and facilitate new forms of scholarship. For more information about JSTOR, please contact support@jstor.org.

The Royal Geographical Society (with the Institute of British Geographers), Wiley are collaborating with JSTOR to digitize, preserve and extend access to The Geographical Journal 
made available, Dr. F. Noetling having undertaken to prepare it for publication. A portrait of the traveller is given in the Deutsche Rundschau für Geographie for July last.

\section{CORRESPONDENCE.}

\section{African Languages.}

THE importance of language in relation to political and social aspects of the native question in Africa seems liable to be overlooked. The possibility of large groups of tribes, hitherto distinct and mutually antagonistic, becoming rapidly able and eager to understand each other in some common form of speech, has apparently to be taken into account. Twenty-six years' contact with Swahili and various dialects of Eastern and Central Africa points so far to the conclusion that there is a remarkable degree of similarity, amounting in many important respects to substantial identity, in the grammatical structure of language over the whole vast area occupied by the Bantu races of Africa, from the Sudan to the Cape. And the stock of words common to all Bantu tribes, when recognized under their various dialectic disguises, will probably prove very considerable.

The officials, missionaries, traders, settlers, and travellers of various nationalities who are qualified to give help in testing this conclusion by personal and first-hand study of a Bantu dialect are naturally difficult to reach, scattered in remote and often isolated spheres of work. It is, therefore, perhaps justifiable to ask publicity for the request, that persons so qualified and willing to accept and reply to a brief communication on the subject would send me their addresses at Fort Jameson, North-Eastern Rhodesia.

I should be grateful if foreign journals and local papers in Africa, general and official, would assist by calling attention to my invitation.

A. C. Madan,

Student of Christ's Church, Oxford.

c/o The British South Africa Company,

Fort Jameson, North-Eastern Rhodesia, July 12, 1906.

\section{GEOGRAPHICAL LITERATURE OF THE MONTH.}

\section{Additions to the Library.}

By FDWARD FEAWOOD, M.A., Librarian, R.G.S.

The following abbreviations of nouns and the adjectives derived from them are employed to indicate the source of articles from other publications. Geographical names are in each case written in full :-

A. = Academy, Academie, Akademie.

Abh. = Abhandlungen.

Ann. = Annals, Annales, Annalen.

B. = Bulletin, Bollettino, Boletim.

Col. = Colonies.

Com. $=$ Commerce.

C. $\mathbf{R}$. = Comptes Rendus.

E. $=$ Frdkunde.

G. = Geography, Géographie, Geografia

Ges. = Gesellschaft.

I. = Institute, Institution.

Iz. = Izvestiya.

$\mathbf{J}_{.}=$Journal.

Jb. $=$ Jahrbuch

k. u. k. = kaiserlich und königlich.

M. = Mitteilungen.
Mag. = Magazine.

Mem. (Mém.) = Memoirs, Mémoires.

Met. (mét.) = Meteorological, etc.

P. $=$ Proceedings.

R. = Royal.

Rev. (Riv.) = Review, Revue, Rivista.

S. = Society, Société, Selskab.

Sc. $=$ Science $(\mathbf{s})$.

Sitzb. = Sitzungsbericht.

T. = Transactions.

Ts. = Tijdschrift, Tidskrift.

V. $=$ Verein.

Verh. = Verhandlungen.

$\mathrm{W} .=$ Wissenschaft, and compounds.

Z. = Zeitschrift.

Zap. = Zapiski. 